\title{
Surveillance \& Society Representations of Surveillance and
Perceptual Technologies at Military Museums
} Article

Kevin Walby

University of Winnipeg, Canada

k.walby@uwinnipeg.ca
Haley Pauls

University of Winnipeg, Canada

haley.nicole0303@gmail.com

\begin{abstract}
Drawing from fieldwork at military museums across Manitoba, Canada, we explore the objects and narratives used to curate museum displays featuring what Bousquet (2018) calls "military perception." Using Bousquet's categories of military perception to organize our analysis, we examine how these museums position scopes, sonars, camouflage, and other devices meant to create visibility or invisibility as aesthetic objects rather than as instruments enabling state violence. With a focus on curatorial strategies and the arrangement of objects at these museums, we explore how surveillance and camouflage displays are organized to minimize the harm that military interventions cause and align the affect of the viewer with the form of Canadian nationalism animating the museum and against "enemy" others and spaces, a process we refer to as encasement. In conclusion, we reflect on what our analysis adds to literature on military museums and representations of surveillance.
\end{abstract}

\section{Introduction}

Museums are full of displays and relics meant to create the feeling of authenticity (Macdonald 2008, 1998; Edensor 2001). Military museums are emerging as part of a global trend toward commemorating atrocity and suffering (Williams 2008), which, in the process, end up commodifying war. In Canada, military museums and heritage spaces have long galvanized citizens to support the state and fostered national identity (Taber 2020; Wellington 2017; Vance 1995). However, meanings in museums are not set or complete. Military museums tend to omit from their displays the violence and suffering that are all too apparent in actual war (Shah 2017a). Shah (2017b) argues that such museum displays tend to depict military interventions and killings as conventional and acceptable, while Lisle (2006) suggests that military museum displays tend to neutralize public understandings of the violence of war.

Many previous critical studies of war museums have focused on representations of weapons on display in military museums. Our focus is on military museum representations of what Bousquet (2018) calls "military perception," including surveillance and camouflage. Bousquet (2018: 2) argues that killing "would be inconceivable without a dense array of perceptual technologies permitting the timely detection, identification, and tracking of its targets." The deadly connection between perceptual devices to aid the use of weapons can be obscured or skewed in military museums. We focus on curatorial strategies and the arrangement of objects at these museums, both for physical relics and smaller text- or ideas-based displays. Viewing these representations of military perception in abundance is akin to encountering what Tawil-Souri (2016) calls the "surveillance sublime," an idea that helps us think through practices but also representations of surveillance. For Tawil-Souri (2016), the key to understanding surveillance is viewing any attempt at monitoring as involving a quest for omniscience (see also Lisle 2006). Such omniscience relies on ways of sensing and mapping among other forms of visualization. Military museum displays of surveillance

Walby, Kevin, and Haley Pauls. 2021. Representations of Surveillance and Perceptual Technologies at Military Museums. Surveillance \& Society 19(1): 37-52. 
technologies are a quintessential depiction of the surveillance sublime of the state. By focusing our attention on displays of perceptual technologies, we tease out a fraught relationship between technology's promise of sublime omniscience and the obfuscated gaze of the museumgoer. Examining the meanings communicated at these museums, we explore how surveillance and camouflage displays in museums are organized to neutralize the harm caused by military interventions and instead align viewers with the Canadian nationalism animating the museum against "enemy" others and spaces, a process we refer to as encasement. Encasement refers not only to the material process of curation but also to an epistemological practice of domesticating weaponry and military equipment as well as naturalizing a friend/enemy binary that is mapped onto spaces and peoples both past and present.

Drawing from fieldwork at seven under-examined museum sites in Manitoba, Canada, and using Bousquet's (2018) categories of military perception to organize our analysis, we explore the representational devices used to curate military museum displays. We demonstrate how these museums position and describe scopes, sonars, camouflage, and other visibility or invisibility devices as aesthetic objects that naturalize martial viewing and detach the devices from their histories as instruments enabling state violence. In the discussion, we reflect on what our analysis adds to literature on military museums and representations.

\section{Context and Literature}

\section{Museums and Meaning}

Our investigation is informed by research in the fields of critical heritage studies and critical museum studies that explores issues of power and ideology in museum spaces. Museums create ideological messages that shape public views of the issues being depicted (Pearce 2017), sometimes communicating subtly racist and sexist ideas (Butler 2007). Distortion can occur in history museums, skewing accounts toward certain political ends (Crane 1997). Museums can also be curated in ways that eliminate some histories and thereby erase the guilt or shame that those histories would otherwise be associated with (Mason and Sayner 2019; Winter 2010; Dickinson, Ott, and Aoki 2006; Dickinson, Ott, and Aoki 2005).

Military museums can be controversial spaces for a few reasons. Members of the public as well as past and present soldiers may contest academic and critical forms of curation (Dean 2009; Bothwell, Hansen, and Macmillan 2008), preferring a more martial interpretation. Military museums are also sites of deeply personal commemoration (Whitmarsh 2001). Winter (2012) argues that military museums at their best are semi-sacred spaces that can compel contemplation. However, when guns and weapons are the main focus violence can become trivialized as museums are rendered places where "boys put their toys on display" (Winter 2012: 12) without context or reflection. Because there are collection thresholds imposed by the training of the curators, the political and economic ties of the museums, and the physical limits to what can be put on display, museums are restricted in their ability to depict difficult histories (Haymond 2015). It is certainly not easy to convey the malicious nature of war or the nuances of life during wartime (Ehrenreich and Klinger 2014) in these spaces.

The tendency in military museums has been toward the display of relics that are treated as war trophies (Matthews 2013). Military museums may also engage in forms of nationalist memorialization, and these practices may deflect attention from complicity in colonialism or atrocities of war (Mead 2012). Often the representations and relics appearing in military museums are sanitized and one-sided in their portrayal of past events (Scott 2015). Gieryn (1998) calls this approach to museum design and curation a defensive epistemology, a pre-emptive approach to curation and managing controversial representations.

\section{Military Perception on Display}

The battlefields of World War I or World War II entail closer deadly relations with the ostensible enemy than today's wars, which are often fought at a distance (Andersen 2014; Wall and Monahan 2011; Der Derian [2001] 2009). Past and present, there are many sensory and visual practices that occur from a distance that make the carnage of war apparent for all those involved. Bousquet (2018) draws from Paul Virilio's 
(1989: 4) influential text on military perception, which suggests that "a war of pictures and sounds is replacing a war of objects (projectiles and missiles)." Building on conceptual approaches to war, space, and speed, Bousquet (2018: 15) offers a "machinic history" focused on the meanings and capacities of military devices, exploring the way vision has become increasingly analogous with death on the contemporary battlefield. Bousquet's (2018) theory of military perception has six components. First, "perspective" refers to mathematical and geometric visualizations in early war. Second, "sensing" refers to scopes, goggles, locators, and other technological aides. Third, "imaging" refers to cameras, reconnaissance, satellites, and other visualization machines. Fourth, "mapping" refers to newer geospatial war techniques and other analytical techniques. Fifth, "hiding" refers to camouflage, barriers, obfuscations, and other means of evading targeting. Finally, "targeting" refers to aiming, ranging, tracking, and guiding. Sensing, imaging, and mapping work together to "align perception and destruction" (Bousquet 2018: 8). The better the alignment, the more devastating the injury. Below, we draw from Bousquet's categories to organize our data analysis. Despite how important Bousquet's (2018) machinic history is as a form of socio-historicalpolitical intervention, we also attempt to bring the corporeal and what we call "tangents" back into the frame of machinic analysis. We do so precisely because of the tendency of the military museum to erase bodies, corporeality, and carnage from these representations (Shah 2017a).

In the battlefield as well as in the museum, the visual and the martial overlap. Military force is based on deception as well as images or representations such as maps (Virilio 1989: 5). Troops must be supplied with images, representations, and information about a space to render it intelligible for attacking. Bousquet (2018) argues that these images and representations enact the spaces that interventions are then made upon. Thus, military perception devices enact martial views of the world that rely on already encoded ideas of who is a friend and who is an enemy. It follows that military representations and the technologies that assemble them also enact military futures when deployed in museums. Museums are organizational spaces that reflect the principles of those who curate them (Yanow 1998). Military museums and the displays pertaining to surveillance and camouflage reflect a martial approach to space, one in which secrecy is strategically deployed. In this way, the military museum is an example of a public secret or secret's publicity (Bratich 2006). For Bratich (2006), secrecy is no longer something held at a distance from the citizenry. Secrecy is integrated into the public and integrated into the spectacle. Today's state manages controversy through "spectacular secrecy" (Bratich 2007). Part of this entails issuing "preventive revelations" and sharing occulted evidence (Bratich 2007: 45).

There is more in the military museum than just the promise of a revelation of a past secret. Like military perception itself, the museum creates a distance between the viewer and context. The rationalization of looking in the museum renders the spaces of military intervention and conflict as linear and singledimensional. In these spaces, there is a re-encoding of the martial view of the world and the place of the museumgoer within it. Military museum displays of surveillance regularize a way of seeing composed of foreign lands and enemy peoples. By highlighting this relationship between the visual, the martial, and space, this article builds on a tradition in museum studies focusing on representation but extends these inquiries by considering the material-semiotic practices that produce a social geography of military intelligibility by positioning military perception in a benign manner, a process we refer to as encasement. Encasement is a curatorial practice of domesticating weaponry and military equipment as well as naturalizing a friend/enemy that is mapped onto spaces and peoples during military conflict and then again in the museum as a way of legitimizing war making.

It is well known that the military engages in the creation of secret-keeping spaces (Paglen 2010) as well as zones that rely on a friend/enemy dichotomy. We argue that the military museum enacts and encases a similar space that authorizes secrets and advances a friend/enemy lens. The idea of encasement is indebted to literature that addresses the geographies of military preparation, training, and research (Heffernan 1996; Woodward 2005). Secret and friend/enemy spaces create particular subjects, one of whom is the museum visitor. 


\section{Research Design and Methods}

Our approach contributes to critical museum studies, which focuses on the role that museum representations play in reproducing the status quo political and symbolic order (McTavish 2013). From this perspective, museum objects and representations must be examined for their latent and symbolic meanings (Ott, Aoki, and Dickinson 2011). Representations are vessels of meaning-making, yet the vessels are always limited in what aspects of reality they can construe. Representations play a key role in the ideological construction of reality (Hall 1997).

Military history and representations are central features of the Canadian province of Manitoba. We conducted observations at the Manitoba Dragoons Museum, Fort Garry Horse Museum, Legion House Museum, Highlanders of Canada Regimental Museum, Combat Services Support Museum, Royal Winnipeg Rifles Regimental Museum, Naval Museum of Manitoba, and Royal Canadian Artillery Museum. Many of these museums are located inside active armouries. The Dragoons Museum is located at the Brandon Armoury in Brandon. The Fort Garry Horse Museum is located in the McGregor Armoury in Winnipeg. The Highlanders of Canada Regimental Museum, the Combat Services Support Museum, and the Royal Winnipeg Rifles Regimental Museum are housed at the Minto Armoury in Winnipeg. The Naval Museum of Manitoba is located in the naval reserve base for HMCS Chippawa, and the Royal Canadian Artillery Museum (RCAM) is located at Canadian Forces Base Shilo, near Brandon. The Legion House Museum is home to the Military History Society of Manitoba and is located at the Royal Canadian Legion in St. Boniface. In Canada, a legion is a pro-military space for retired military people and their families. There are military pamphlets and magazines such as The Brigade and The Western Sentinel available at all of these museums.

Though most of these museums are located in close proximity to active military spaces, they differ in terms of range and scope of representations. These museums share a sanitized approach to the carnage implicit in perceptual technologies and to guns in general, although certain museums stand out in their attempts to centre the human experience of war, such as the Royal Winnipeg Rifles Regimental Museum (RWRR). The slight differences we found in each of the museums studied were often due to location and funding as well as the approach of individual curators. The phenomenon of the small military museum located adjacent to a military base is a space that is usually overlooked in favour of larger, national museums like the Canadian War Museum. Though some small museums like the RWRR gesture to the human experience through the inclusion of items like personal letters, they maintain a tendency to decontextualize surveillance technology, rendering scopes, sonars, and maps "objects of interest" rather than tools used for killing. This aestheticization of surveillance technology, despite differences in curatorial maintenance and approaches (the Combat Service Support Museum, for example, has not been updated in a number of years, whereas the RWRR was recently re-curated), suggests an overarching detachment between the military's bodily experiences of war and surveillance technology in the information age.

While some museums were only attended once by one author, others, such as the Royal Canadian Artillery Museum (RCAM), were attended multiple times by both authors. At each museum, we took fieldnotes (Wolfinger 2002) on the displays and placards, identifying relics and representations related to surveillance. After the initial visits, we used Bousquet's (2018) categories of military perception to organize our analysis, though we identified additional themes using open coding (Ryan and Bernard 2003). State information and archives are notable for missing more records than they contain (Galison 2004). This finding has implications for thinking about what one sees in a military museum. Therefore, we are also attuned to tracing missing or absent materials and knowledges (Meyer 2012) in these spaces. Most of the physical relics in the military museums we examine are from what Bousquet (2009) calls the mechanistic and thermodynamic eras of war, that is the pre-Cold War era. However, we also discuss some Cold War and War on Terror era displays, which depict the changing surveillance technologies of later eras.

We acknowledge that interpreting objects in the museum is not a straightforward process and that objects have potentialities shaping how they can be curated (Dudley 2018; Luscombe, Walby, and Piché 2018; 
Walby, Piché, and Friesen 2018). Another limit of this study is that we have not interviewed museum visitors about their experiences or interpretations. These interpretations of encased military relics and visions are informed by our theoretical stance and readings of critical military studies, critical heritage studies, and critical museum studies.

\section{Findings and Data Analysis}

\section{Perspective}

Military perspective requires the mathematization of space and the plotting of enemies in that realm. There are several museum displays we encountered that represent this facet of military perception. The Fort Garry Horse Museum is designed to display the history of the Armoured Reconnaissance Unit through the use of artefacts, photographs, and archival material. In this museum, there is a chart displaying the components of the original cavalry regiment deployed in the Canadian prairie provinces that includes a signals section. The signals section is comprised of several horse-riding soldiers who conduct surveillance and signal findings back to the signals officer and the officers of the supporting corps. These troops are placed in a Cartesian military space and moved like pawns to conquer enemies and enemy space, as were the North West Mounted Police (NWMP) in the Canadian prairie provinces as part of colonization (see Monaghan 2013), making it appear as though Indigenous peoples were an enemy to be outflanked by agreeable Mounties. Also at the Fort Garry Horse Museum, there are displays of a number of maps that demonstrate a mathematization of space and the plotting of enemy whereabouts for both the Germans and for Allies in World War I. Additionally, there is a display about an aircraft observers' plotting board used to map enemy trenches and positions across swathes of territory. The observations are drawn on ruled paper, a geometric and linear device for mapping. These mathematical plottings de-materialize atrocity and suffering, but they also begin to encase the space of military intervention as foreign and alien.

For Bousquet (2018: 21), "the rationalization of vision and the mathematization of space" is crucial to military perception, as it begins the process of perceiving enemy positions and making military space or enemy space intelligible. Rationalization and mathematization are also crucial to museum representations of war and military surveillance. The displays described above represent the mathematization of space and the plotting of enemies. The viewer is instructed in the same way of making the world intelligible that military perception makes possible, by calculating and locating enemies.

\section{Sensing}

Bousquet (2018) notes that telescopic seeing was a prized skill in pre-Cold War military operations, involving many devices invented for sensing. There are several museum displays that represent this facet of military perception. Exhibitions at the Legion House Museum suggest that the power of sensing is a game of military perception. One display describes the military use of heliographs (see Figure 1), which are wireless telegraphs using flashes of sunlight to communicate messages across space. Another features a signalling lamp used on Canadian Navy ships. Heliographs and signalling lamps weaponize light itself (Bousquet 2018), though the displays do not make this deadly intention apparent. Also at the Legion House Museum, there is a display on Royal Canadian Air Force training in Manitoba and training in aerial surveillance, including devices used for surveillance by pilots and reconnaissance officers in flight. The museum also displays a radioactive nuclear calculator kit from the 1970s carried by soldiers in case of nuclear attack.

At the Fort Garry Horse Museum, a pair of binoculars belonging to a soldier who landed on D-Day and a compass carried by tank crew commanders are on display. These devices are never connected to the actions of the soldiers, and the violence implied in their usage is not broached. Similarly abstracted from violent histories are the periscopes on display at the Fort Garry Horse Museum. The museum also features a replica of a trench periscope and other trench periscope materials, including a spotting telescope used in conjunction with binoculars for "observation of enemy positions," according to the placard. Similarly displayed with no reference to their killing histories, these devices are turned into artefacts and encased as inert instead of 
being treated more precisely as machines that enable violence (Pauls and Walby 2020). Fetishizing hardware instead of contemplating its deadly use (Bruggen 2016), this martial mode of visualization goes unproblematized.

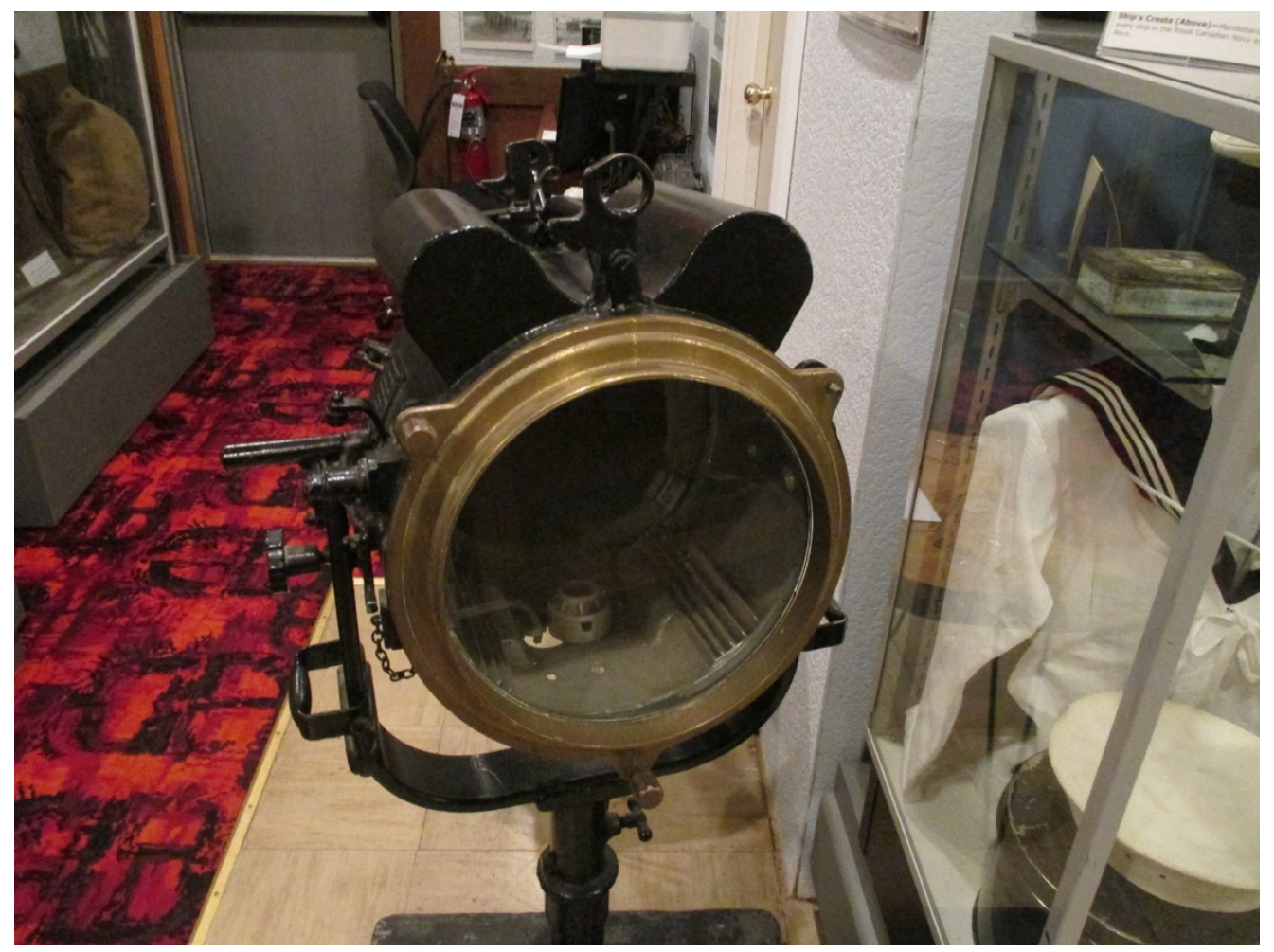

Figure 1: Signalling lamp and sensing. Photograph by Kevin Walby at Legion House Museum, 2020.

The Royal Winnipeg Rifles Regimental Museum (RWRR) similarly fetishizes periscopes and sensing technology from the World War I and World War II eras. The RWRR is a small museum with only a few rooms, and in one there is a large replica periscope on display with pieces of glass placed inside so that if viewers look at a glass piece at the bottom they can see across the room. There is no placard beside the item, but it is assumed to be another early iteration of the periscope used in trench warfare. An adjacent glass case displays an array of gear used during the world wars, specifically related to trench warfare. The gear reflects the developments that Canadian troops saw in response to gas attacks instigated by the German army. The museum makes a point of emphasizing that the German army initiated the gas attacks, encasing them as the enemy. The case shows a German periscope, which was used to view and surveil enemy troops without leaving the trenches. There are a few kinds of binoculars featured as well, which point to the need to see enemy movements from afar during trench warfare. Next to the German periscope and binoculars, a number of different kinds of gas masks are on display. It is notable that the gas masks that are featured here are all Canadian. The first mask on display is an early variant "made of a piece of cloth with eye pieces circa 1915" that the placard calls "a step up from a urine-soaked handkerchief." The second is "The P Helmet—the white hood with breathing tube circa 1915-soldiers found this design too claustrophobic and it would not protect from gas when wet." The last one featured is "the Small Box Respirator, circa 1916-17, with Brodie helmet, the most effective design to date." In short, this display at RWRR depicts Germans as a group of deadly "sensors" and the Canadian Rifles Battalion as the quick responders to the threat that they posed. It implies that both the Germans and the Allies adopted similar technology in this war but frames the Germans as the initiators. The museum depicts the Canadian troops as taken aback by Germany's ability to enact these harmful, calculated attacks and encases this by presenting the poorly designed first iterations of the Canadian gas masks, indicative of this rushed response. 
Sensing technology commonly appears in Manitoba military museums as relics used to create martial narratives. These relics, including heliographs, signaling lamps, periscopes, and binoculars, are often either encased as objects of interest or as dangerous enemy developments. The relationship between these items and bodily threats are often obscured or associated with the enemy. This obfuscation is furthered by the fact that sensing technology does not always look deadly in itself and can easily function to mitigate associations made between the Canadian military and the infliction of harm and death. Sensing is often depicted as a historical game with fatalities and harm sidelined. These are some of the curatorial techniques through which museum displays make war seem "defensible, even desirable" (Shah 2017a: 99).

\section{Imaging}

Photography provides military planners with more accuracy and aids in the precision of killing (Bousquet 2018). The emergence of digital and electronic imaging generates further precision. Many of the museums we studied represent this facet of military perception. At RCAM, there are a number of larger radar trailers. These vehicles are described as support mechanisms for military operations: "It received the approximate range and bearing of incoming targets from the Zone Position Indicator... [the device] then provided accurate measurements of range, bearing and angle of each target aircraft to direct the fire of a Troop of four 3.7 heavy anti-aircraft guns" (see Figure 2). For Packer and Reeves (2020: 37), such devices are about recognizing foes to intercept but also recognizing friends to leave unharmed. These techniques emphasize the awe-inspiring forms of state power and grandeur that aspire to omniscience, or the surveillance sublime (Tawil-Souri 2016). Sublimity refers to the extraordinary, overwhelming feeling of some display. Potolsky (2019: 16) explores the sublimity of state power, calling it "a public secret." State power, they suggest, is manifested as sublime when the public is aware of its power but lacks specific knowledge of its capabilities and reach. The coupling of awareness and lack of grounded knowledge creates an overwhelming sense of state sublimity among citizens. The displays of military surveillance at RCAM aspire to such an elevation, and it is exactly this idea of the surveillance sublime that the museum communicates with its imposing arrays of surveillance devices and weaponry.

At the Fort Garry Horse Museum, a series of photographs outlines the importance of imaging technologies to the development of the Fort Garrys. A picture from 1982 shows the Regimental 70th Anniversary parade with military personnel driving a Lynx Armoured Reconnaissance vehicle. This vehicle was withdrawn from use in 1993 but is still on display outside the Fort Garry Horse Museum and, according to a pamphlet, has "been adopted by local children as a popular play structure." There are pictures of members in official regalia posing in front of many other Reconnaissance vehicles. There is also a patch worn by a regimental competition troop. Bousquet (2018) explains that reconnaissance patches are markers of status in communities of surveillance and imaging specialists. Another picture shows an observation helicopter dated 1963, in Germany, that was serving as part of the Reconnaissance Squadron. Members of Fort Garry piloted the helicopters. A subsequent photograph shows a group of soldiers from the Reconnaissance Squadron in 1964, in Germany. In another, soldiers appear posing in front of the Eaton Cup, which was awarded in an annual skills competition, notably for shooting. With the soldiers smiling and posing in their war machines, these photos create a positive affective relation between the soldiers and the viewer but, at the same time, neutralize the role of reconnaissance in killing. The next photo shows the Fort Garry Horse unit posing in the desert of Afghanistan. This series of images demonstrates the centrality of advanced imaging technologies to the Fort Garrys and also the centrality of the Fort Garrys in military perception. Imaging is a means of military perception, but, when on display in the museum, this imaging naturalizes this martial vision in the contemporary period along with the necessity of secrecy and the friend/enemy dichotomy encased in these scenes. 


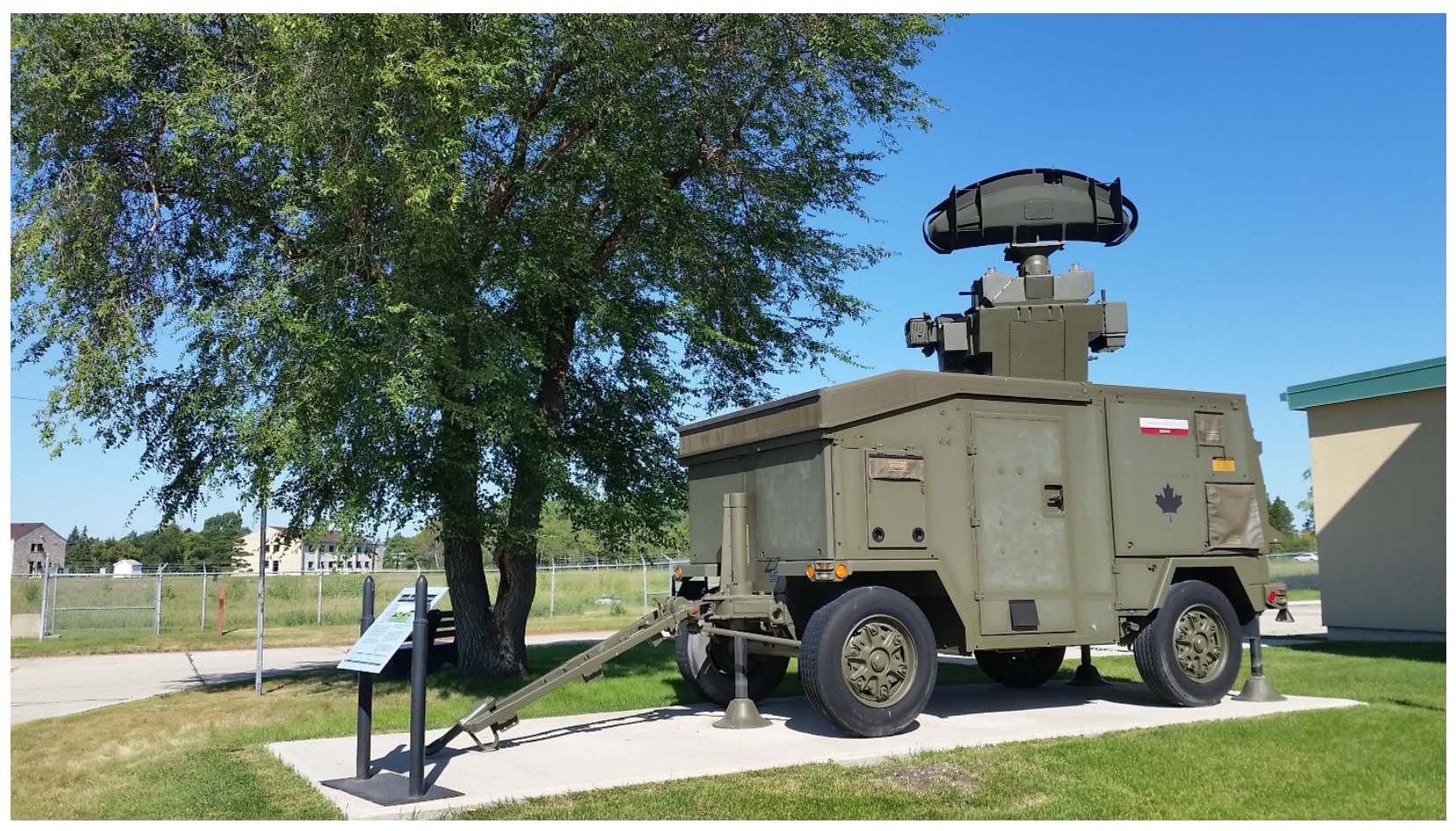

Figure 2: Imaging and the surveillance sublime. Photography by Kevin Walby at Royal Canadian Artillery Museum, 2019.

\section{Mapping}

Mapping is intertwined with both perspective and imaging (Bousquet 2018), referring to the way that technologies translate into mentalities and practices of war. An example appears at the Legion House Museum, where training maps used at a site called Camp Hughes are on display. Camp Hughes was a site near Brandon, Manitoba that was transformed to resemble the theatre of operations for World War I. In preparation for deployment, thousands of soldiers and military personnel occupied mock trenches in this war simulation zone for days at a time. The maps on display at the Legion House Museum were used at Camp Hughes to train soldiers to read maps and apply them to terrain. The museum also features D-Day maps that appear ceremonial or propaganda-oriented, displaying over-emphasized sweeps and motions of battalions. There is also a set of maps depicting Nazi-captured territories and flows of soldiers and military vehicles as well as escape maps carried by soldiers in case of estrangement. As the display reveals, the detailed escape maps were made on silk and tucked into the uniform of the Royal Canadian Air Force members.

Modern maps from Afghanistan that are more detailed than the maps from World War II are also included. One geocoded map (see Figure 3) of what appears to be Kandahar is labelled "RESTRICTED" and shows actions by five military groups named after National Hockey League teams. Given the nationalist sentiments attached to hockey in Canada, such an approach to mapping and curation immediately encases and thus naturalizes the friend/enemy dichotomy. This knowledge move re-instantiates the discursive framework of the War on Terror, both in the field and in the museum. The inclusion of a classified file also creates some allure for the viewer. This is consistent with our claim that the secret's publicity (Bratich 2006) in the realm of the military must be modulated even in spaces such as museums. Too much knowledge too soon would counter the martial forms of viewing that the museumgoer is being invited to participate in. 


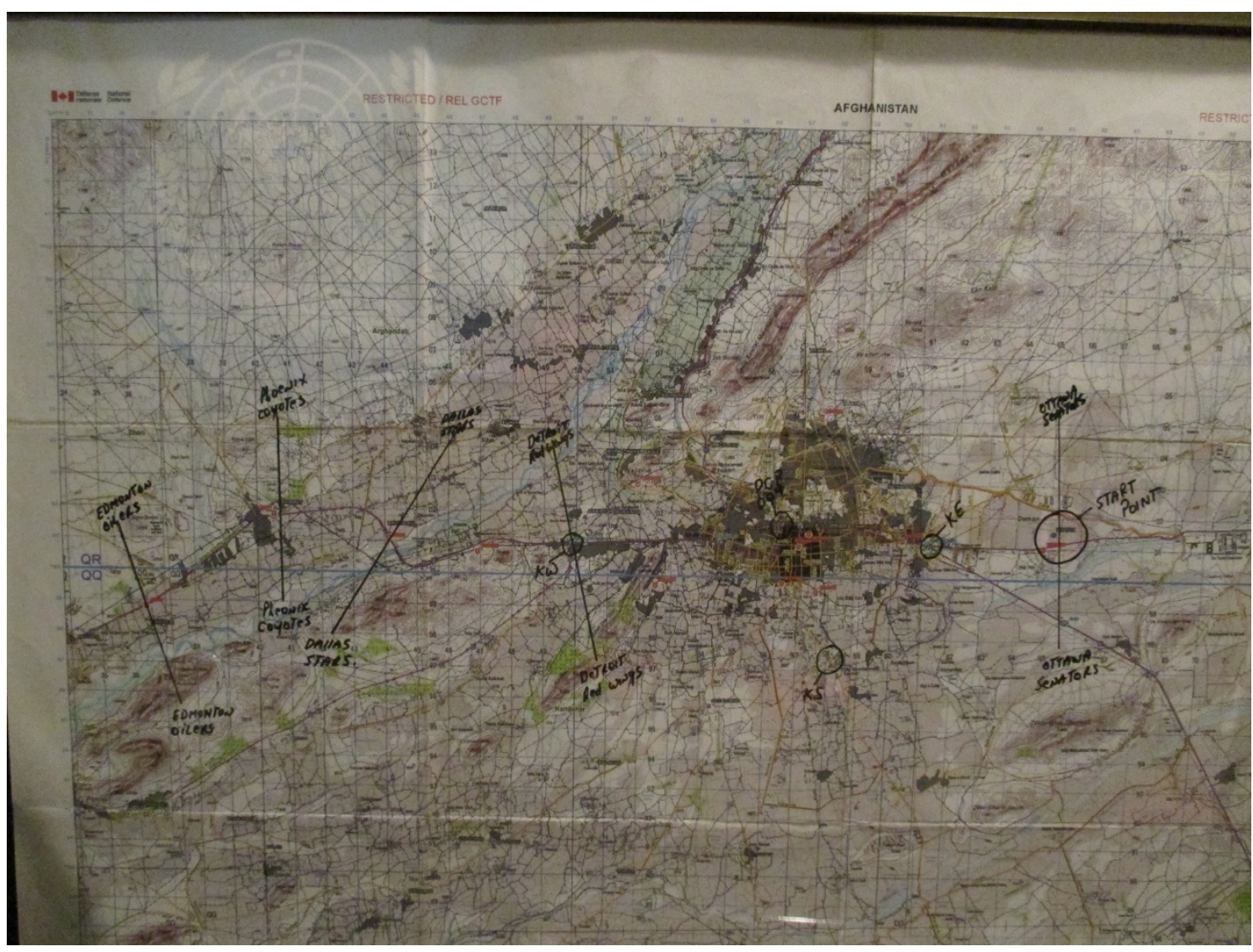

Figure 3: Hockey night in Kandahar map. Photograph by Kevin Walby at Legion House Museum, 2020.

Military mapping, measuring, and planning creates martial space. By depicting space as being of strategic consequence, practices of mapping render space into objects of risk, volatility, or danger. The textualized representations of space, including maps and the descriptions of enemy terrain at the heart of military maps, offer new possibilities for how a space can be surveyed or intervened in. The space enacted in the representations of military planners creates the possibility of military targeting. Museum maps also make the spaces intelligible through the same categories, encasing them as historical fact and projecting them onto future state actions and citizen-state relations. The maps on display in the museum become ways of reinstantiating secrecy and the friend/enemy dichotomy that military space relies on to begin with.

\section{Hiding}

Camouflage exists to foil the military gaze (Bousquet 2018). Creating obfuscation in a material or electronic fashion can save one's life, though it is also oriented toward assuming a position to make one's own kill. The development of new weapons requires new forms of camouflage, which in turn requires new weapons (Packer and Reeves 2020: 41). At the Fort Garry Horse Museum, there are several displays on combat dress and the use of uniforms as camouflage. These displays trace the changes in uniforms and camouflage related to the geographies in which military operations are performed. At the Legion House Museum, there are several pictures of World War I trenches, which are a form of cover or obscurity in the battlefield. Several mannequins in camouflage carrying maps also appear. Most are from World War II but one is adorned in a Tim Hortons Coffee camouflage hat from Afghanistan. The Canadian military had a Tim Hortons Coffee shop installed at their base in Kandahar, Afghanistan. Given the nationalist sentiments attached to Tim Hortons Coffee, such an approach to curation can align the affect of the soldier to the state via the coffee corporation and can subsequently align the museum viewer with the soldier (Sutherland 2014; Hanks 2012) 
or friend instead of the supposed enemy. Even recent history can be encased and framed using the same curatorial techniques.

In exhibits depicting the Cold War and post-Cold War eras, we found that representations of hiding and camouflage were focused on information rather than garments. In a section of the RWRR dedicated to the regiment's involvement in the Cold War, a number of pamphlets on display explain how to survive a radioactive attack using evasion tactics. As war technology became more devastating during the Cold War, forms of hiding and evasion changed in response to the far-reaching threat of nuclear warfare. This exhibit demonstrates a notable change in tone, which can be attributed partially to the fact that, during the Cold War era, hiding tactics became normalized as the job of the regular citizen and not only of the soldier.

As such, in this exhibit different items are on display, including several colourful pamphlets with titles such as "your basement fallout shelter" and "11 steps to survival," indicating that during the Cold War the battlefield had become increasingly realized as "coterminous with the globe" (Bousquet 2018: 2). As the display suggests, the terrain of surveillance inflicted by the military was no longer confined to military bases or war-zones. Throughout the mid-twentieth century, citizens became detectors of and responders to nuclear war. Though citizen engagement with global military surveillance regimes indicates a transfigured battlefield, it does not indicate a system of full transparency. Even as the citizen becomes engaged and the previously fixed image of the military field is expanded, the martial gaze remains a public secret.

The pamphlets at RRWR are aestheticized within a history of images from the 1940s and 1950s, such as Bert the Turtle (the famous protagonist of a series of "Duck and Cover" videos) and other propaganda responses to the threat of nuclear war. The placement of these pamphlets indicates the expanding "struggles over visibility across planetary battlespaces" (Bousquet 2018: 3) during the Cold War (and arguably the beginning of World War II). The bright colours and line drawings of nuclear families in dated clothing that characterize the pamphlets indicate a farcical element to the rhetoric of the Cold War response pamphlet, suggesting that effective public response to nuclear warfare was possibly delusional in the first place (see Masco 2005).

This tactical evidence from RWRR shows how an emphasis on symbols, descriptions, and categorization became crucial during the Cold War period, as the West struggled to enact a surveillance regime upon the Soviet Union. The Canadian military increased its emphasis on enemy identification and hiding strategies in response to anxiety over the threat of mass-targeting strategies posed by the invention of the atomic bomb. The exhibits suggest that, during these times, the military became focused on the dissemination of information, encouraging the military and the public to recognize and respond to nuclear attacks while still reinforcing state secrecy and thus normalizing the friend/enemy dichotomy as a facet of daily life.

\section{Targeting}

Bousquet's definition of targeting comprises four steps, including taking aim, measuring, tracking, and guidance (Bousquet 2018). The goal of targeting is to kill. Bousquet (2018) explains that with contemporary war technology comes the increased possibility for targeted attacks. At the Fort Garry Horse Museum, many guns are displayed. Often the gun sight is the central feature of the display, inviting participation in targeting. Often there is little information included about the guns, though some of the guns are curated so that one can look down the gun sight and get the feel for what it is like to be in the military. There is likewise a display for a range finder that could be mounted on a machine gun and anti-aircraft weapons (Figure 4). With a range of ten thousand meters, it could be handheld or mounted on a weapon. A sighting telescope for use on medium- and long-range guns on a tank is also featured in this space. 


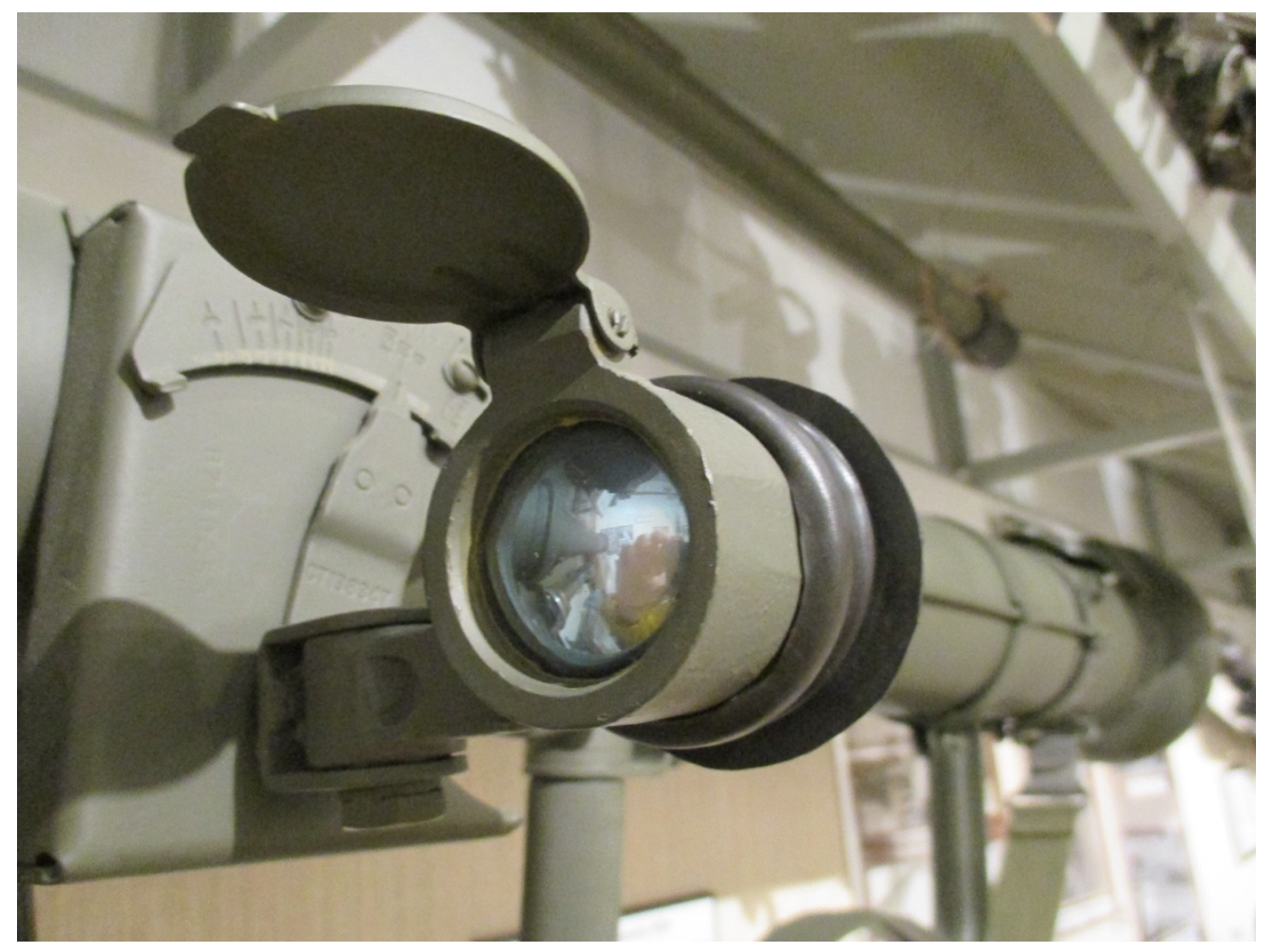

Figure 4: Targeting range finder. Photograph by Kevin Walby at Fort Garry Horse Museum, 2020.

At RCAM, a number of Honest John Missile Loaders and Surface to Air Missile launchers are on display. These are weapons that have the capability for measuring and tracking, with computer guidance for precise targeting built in, demonstrating the automation and computerization of killing and military action. As another display of the surveillance sublime, the relics are positioned one after another and book-ended on either side by large weapons that are overwhelming and intimidating. Such displays that lack context may create a distorted awareness of the deadly violence inherent in war and soldiering (Danilova and Purnell 2019). Many museum gun displays are presented through a disorienting aesthetic of the sublime, obscuring their violent ability to target. In addition to the obfuscation created through the overwhelming arrangements of guns in museum spaces, we noticed an idealization of precise technology, associated with Canada and "the West," in comparison to an abject otherness associated with broad attacks or killing frequently conflated with non-Western spaces.

At RWRR, a section described by an accompanying placard entitled "Post-2001: Asymmetrical Warfare," extends an association that began in its exhibit dealing with the Cold War, conflating the West and the rational responses to broad attacks. The "Post-2001" section of RRWR is organized similarly to its Cold War exhibition, based around a set of brochures. The brochures are presumably addressed to military personnel themselves, outlining how to recognize a suicide-bomber, listing and explaining various possible identifiers of such an attack. One pamphlet explains that Vehicle-Borne IEDs can "come in all shapes, colors and sizes: from simple passenger cars to large delivery or sewage trucks. Sedans are most often used." This pamphlet continues by outlining an extensive description of a type of strategic attack associated with AlQaeda involving decoy vehicles. These depictions sediment an association between "the West," rationality, and acute targeting, associating "othered" global powers, such as the Soviet Union and groups in the Middle East, with the abject process of broad targeting. The curatorial decision at RRWR to use brochures and pamphlets in both displays substantiates a narrative of Western rationality, responsibility, and civic concern in comparison to a depiction of abject and aggressive actions practiced by enemy powers. The displays encase this understanding not only as a historical fact but also as a current outlook for all friendly nations. 
A closer look at military history, and even surrounding displays in the museums at hand, exposes these associations as inaccurate and hypocritical. Western military powers have often used broad attacking strategies that involve mass destruction and sacrifice. Bousquet (2018) is clear in his description of the advent of precision targeting that its development has not necessitated its actualization. He writes that "as a result of human error, technical malfunctions, or merely their inherent margins of operational error, the latest weapon systems still can and do miss their intended targets" (Bousquet 2018: 12). Although Canada (and "the West" in general) has embraced precision weaponry due to increased public aversion to mass armies and casualties, Bousquet (2018: 12) warns that accompanying rhetoric that associates the West with endless military precision "should not be mistaken for its reality." He explains that, with the development of increasingly precise targeting systems, "military planners [on all sides of recent conflicts] have on many occasions willfully chosen the massing of destructive force over wide areas over any efforts toward target discrimination" (Bousquet 2018: 11).

Associations made between Canadian military efforts, rationality, and precision are additionally complicated by displays dealing with themes of national sacrifice. In RRWR a separate room honours the members of the Rifles Battalion who have been lost since it was established. There is a placard in this room with three sections: "Sacrifice," "Injury," and "Death," which establish a narrative of the esteemed sacrifice that soldiers make for their country. In the section entitled "Death," the placard reads: "Soldiers operate under unlimited liability while on active service.... the soldier is unlimited in his or her military responsibilities and, if necessary, must offer up his or her life in the achievement of the mission goal.... It is the concept of service before self."

The hypocrisy of the museum's depiction of Canadian "service" in contrast to suicide bombers" abjection can indicate to the perceptive museumgoer that one of the main projects of Canadian military rhetoric is to create a friend/enemy dichotomy, associating Canada and, by extension, "the West" with desirable traits including rationality and humanitarianism. Canada and the West appear to be associated with the "progressive" nature of precision targeting. This construction ignores Canada's participation in massively destructive regimes, its colonial violence, and its military ethics involving self-sacrifice for the benefit of the state.

\section{Tangents}

As noted above, Bousquet (2018: 15) argues that their work is a "machinic history," which traces the history, the development, and the effects of objects. Many bodies are involved in surveillance and military perception and assemblages, bodies that are not always evident in a machinic history or an object-centered history, which leads us to reflect on several tangents apparent in the museums we examined. The idea of tangents does not simply refer to a digression. It also refers to a refraction or angle that can shed more light on military perception and its representation, one that brings the body back into machinic history. Part of the etymology of "tangent" is a focus on touching or the materiality of the body. Bodies are disquieting and unruly (Leahy 2016), and, when they are brought into the frame, they complete an analysis of the surveillant mechanisms and narratives being displayed. Working through these tangents, we bring bodies as well as subjugated narratives back into Bousquet's (2018) machinic history. These bodies are often constituted as friends or enemies or are obscured in some way.

At the Fort Garry Horse Museum, one of the first displays mentions the 1885 Metis and Indigenous resistance and the North West Mounted Police (NWMP) intervention. Canada is a country founded upon colonial domination (Monaghan 2013). Part of the NWMP intervention entailed surveillance. This display refers to "Boultan's Scouts," who provided reconnaissance for the NWMP. The placard goes on to detail how this unit fought at Batoche, the site of the Metis resistance against the NWMP and the Canadian colonial state. The slide normalizes NWMP actions at Batoche in 1885 as part of the military history of Canada. There is also a display board memorializing the interventions of the Fort Garrys (a NWMP unit) at Batoche and Fish Creek. At the Legion House Museum, there is another display on Batoche and Fish Creek. NWMP colonial intervention and surveillance is prescribed as an origin point for the Canadian military in the museums. We have uncovered displays in a number of the museums that demonstrate that the friend/enemy 
dichotomy has a colonial origin and was developed in a domestic context before being exported for war. These displays also indicate that the friend/enemy dichotomy that military space enacts overlaps with the idea of settler common sense (Rifkin 2013). Any position contrary to colonial domination and government becomes construed as an enemy position. It is important to remember that the omission of the body in military museum spaces is not a random omission. Rather, it is a racially charged practice that serves the purpose of avoiding the subject of colonial and imperial violence.

Canada's fraught history of settler colonialism and desire to omit it from national memory is additionally apparent in a commemorative magazine available at all of the museums entitled Four Centuries of Manitoba Military Heritage that blends together the colonial occupation of what is now called Canada with World War I, World War II, and the so-called War on Terror in Afghanistan. Surveillance of Indigenous communities has been a constant force throughout Canada's history (Monaghan 2013). At the Fort Garry Horse Museum, there is also a display of the Fort Garrys standing by their horses with wooden clubs at the 1919 Winnipeg General Strike. The 1919 Winnipeg General Strike has been called the largest labour mobilization in North American history. The Fort Garrys were led by the NWMP. This display is an example of the friend/foe dichotomy applied to the labour movement in the service of capital, with the labour movement being reframed as a domestic enemy in the interwar period. In the Canadian context, military figures appear to be mobilized first in the service of colonialism, then exported for war efforts, then applied again domestically to trample labour organizing.

Tawil-Souri (2016) argues the surveillance sublime is represented in state efforts to watch over a population and to know everything about that population. These consistently unnerving attempts at omniscience can occur through ancient and also futuristic techniques. This form of cognitive surveillance is apparent in state propaganda and recruitment material. At the Legion House Museum, there is a recruitment poster that notes "Why Aren't You in Khaki? You'll Be Wanted. Enlist At Once." This poster speaks to role of the surveillance of the state in recruiting and monitoring their population to create soldiers. The poster plays with guilt and self-surveillance in an attempt to manipulate would-be soldiers. At the Fort Garry Horse Museum, there is a picture of a machine-gun at a prisoner's barracks at Red Rock, Ontario with the view from a guard tower. Prisoners of war in the domestic context were subject to surveillance and state force as a result of racialized military strategy (Auger 2006; Kordan 2002). These tangents bring the subject and the body into the frame of a machinic history of military perception. These tangents also further reveal how museum displays encase the friend/enemy binary fundamental to the martial gaze. They expose the ways that this binary is racialized, usually encouraging alignment with a white settler perspective and suggesting that Indigenous peoples in Canada as well as people of colour in other countries are the enemy. These tangents also uncover the fact that surveillance regimes exceed traditional military representations of interesting periscopes, mapping techniques, and satellites, and, in fact, also include cognitive surveillance and thought regimes. These thought regimes lead to the proliferation of simplistic and short-sighted perspectives that conceive of nationhood through a racialized friend/enemy dichotomy.

\section{Discussion and Conclusion}

We have examined representations of surveillance appearing at Manitoba military museums, using Bousquet's (2018) categories of military perception to organize this inquiry. These military museums are encoded through a friend/enemy dichotomy and through refracted forms of military perception that invite the visitor to either see military practices as the military accepts them or to experience them in an occluded manner. This dimension of the museum mirrors the constitution of military space that military perceptions enacts (Paglen 2010), encasing a reality in which weapons and surveillance devices are rendered benign or entertaining and in which space is viewed through a friend/enemy binary that projects nationalism as a way of interpreting the world. Such restricted approaches to curation are a means of controlling accounts of the past and controlling heritage (Smith 2006). By commemorating the military's past and promising a revelation of military secrecy, the action in the present is to encase and normalize military interventions as well as martial views of space and the way of seeing that military perception devices help enact. Absent in these museums is a sense of how military organizations socialize people into violence and train them to be 
proficient killers, as Blake's (1970) auto-ethnography of military training reveals. Missing representations in military museums could be viewed as a form of camouflage (see Veeren 2018; Shah 2017a).

With their displays of scopes, sonars, camouflage, and other devices meant to create visibility or invisibility, military museums become part of militarism's occluded geographies (Woodward 2005). Surveillance technology occupies a specific place in the trend of domestication and occlusion that occurs in military museum spaces, and, though it is often de-contextualized and aestheticized similar to big guns, its affect must not be interpreted as synonymous. Possibly more easily than guns, surveillance technology lends itself to the category of "interesting artefact," which allows it to be de-politicized in service of constructing a favourable sense of (in this case, Canadian) self. Because of the often-mysterious narrative that accompanies the concept of "surveillance," or the "surveillance sublime," representations of surveillance technology are easily manipulated for nationalist purposes. By interrogating the way Manitoba military museum spaces capitalize on the flexibility of this topic, we are able to gather a broader understanding of Canada's selfimage in contrast with enemy others. Virilio (1989:2) predicted that the world is approaching an age where "eyeshot will then finally get the better of gunshot." If we are to recognize the increasing power of vision, it is essential we also recognize how it may be manipulated and investigate the objects of our gaze.

Military museums naturalize forms of obfuscation in knowledge about war and weapons, both past and present (Daugbjerg 2017). These spaces make military practices intelligible for new viewers by normalizing military sensing, imaging, and mapping in various exhibits, which also normalizes military spaces as well as friend/enemy antagonisms brought into being both past and present. In conducting an analysis of these representations, we have used Bousquet's (2018) approach while attempting to bring the body back into machinic history, which disrupts the common-sense framing of maps and charts but also contributes to the study of museums and cultural representation more broadly. Today, there are ways to use satellites and other visualization technologies to reverse the gaze or to see what is not represented in official state or museum discourse (Perkins and Dodge 2009). It remains to be seen whether these representations of military perception will be jammed or have new light shed on them.

\section{References}

Andersen, Carrie Elizabeth. 2014. Games of Drones: The Uneasy Future of the Soldier-Hero in Call of Duty: Black Ops II. Surveillance \& Society 12 (3): 360-376.

Auger, Martin F. 2006. Prisoners of the Home Front: German POWs and "Enemy Aliens" in Southern Quebec, $1940-46$. Vancouver, CA: University of British Columbia Press.

Blake, Joseph A. 1970. The Organization as Instrument of Violence: The Military Case. The Sociological Quarterly 11 (3): 331350.

Bothwell, Robert, Randall Hansen, and Margaret MacMillan. 2008. Controversy, Commemoration, and Capitulation: The Canadian War Museum and Bomber Command. Queen's Quarterly 115 (3): 367-387.

Bousquet, Antoine. 2009. The Scientific Way of Warfare. Order and Chaos on the Battlefields of Modernity. New York: Columbia University Press.

. 2018. The Eye of War: Military Perception from the Telescope to the Drone. Minneapolis, MN: University of Minnesota Press.

Bratich, Jack. 2006. Public Secrecy and Immanent Security: A Strategic Analysis. Cultural Studies 20 (4-5): $493-511$.

. 2007. Popular Secrecy and Occultural Studies. Cultural Studies 21 (1): 42-58.

Bruggen, Caspar van. 2016. Military Matters: Approaches to the Photographic Collection of the Dutch Army Museum. In Uncertain Images: Museums and the Work of Photographs, edited by Elizabeth Edwards and Lien Sigrid, 181-200. London: Routledge.

Butler, Shelley Ruth. 2007. Contested Representations: Revisiting into the Heart of Africa. Toronto, CA: University of Toronto Press.

Crane, Susan A. 1997. Memory, Distortion, and History in the Museum. History and Theory 36 (4): 44-63.

Danilova, Nataliya, and Kandida Purnell. 2019. The "Museumification" of the Scottish Soldier and the Meaning-Making of Britain's Wars. Critical Military Studies 6 (3-4): 1-19.

Daugbjerg, Mads. 2017. The "Distant War" Up Close and Personal: Approximating Afghanistan at the Danish Arsenal Museum. Critical Military Studies 3 (1): 50-68.

Dean, David. 2009. Museums as Conflict Zones: The Canadian War Museum and Bomber Command. Museum and Society 7 (1): $1-15$.

Der Derian, James. (2001) 2009. Virtuous War: Mapping the Military-Industrial-Media- Entertainment Network. New York: Routledge. 
Dickinson, Greg, Brian L. Ott, and Erik Aoki. 2005. Memory and Myth at the Buffalo Bill Museum. Western Journal of Communication 69 (2): 85-108.

- 2006. Spaces of Remembering and Forgetting: The Reverent Eye/I at the Plains Indian Museum. Communication and Critical/Cultural Studies 3 (1): 27-47.

Dudley, Sandra H. 2018. The Power of Things: Agency and Potentiality in the Work of Historical Artifacts. In A Companion to Public History, edited by David Dean, 187-199. London: Wiley-Blackwell.

Edensor, Tim. 2001. Performing Tourism, Staging Tourism: (Re)producing Tourist Space and Practice. Tourist Studies 1 (1): 5981.

Ehrenreich, Robert M, and Jane Klinger. 2014. War in Context: Let the Artifacts Speak. Does War Belong. In Museums: The Representation of Violence in Exhibitions, edited by Wolfgang Muchitsch, 145-154. Berlin, DE: Verlag.

Galison, Peter. 2004. Removing Knowledge. Critical Inquiry 31 (1): 229-243.

Gieryn, Thomas F. 1998. Balancing Acts: Science, Enola Gay and History Wars at the Smithsonian. In The Politics of Display: Museums, Science, Culture, edited by Sharon Macdonald, 170-196. London: Routledge.

Hall, Stuart. 1997. The Work of Representation. In Representation: Cultural Representations and Signifying Practices, edited by Stuart Hall, 13-74. London: Open University Press.

Hanks, Laura Hourston. 2012. Writing Spatial Stories: Textual Narratives in the Museum. In Museum Making: Narratives, Architectures, Exhibitions, edited by Suzanne MacLeod, Laura Hourston Hanks, and Jonathan Hale, 21-33. London: Routledge.

Haymond, John A. 2015. The Muted Voice: The Limitations of Museums and the Depiction of Controversial History. Museum \& Society 13 (4): 462-468.

Heffernan, Michael. 1996. Geography, Cartography and Military Intelligence: The Royal Geographical Society and the First World War. Transactions of the Institute of British Geographers 21 (3): 504-533.

Kordan, Bohdan S. 2002. Enemy Aliens, Prisoners of War: Internment in Canada During the Great War. Montreal, CA: McGillQueen's Press.

Leahy, Helen Rees. 2016. Museum Bodies: the Politics and Practices of Visiting and Viewing. London: Routledge.

Lisle, Debbie. 2006. Sublime Lessons: Education and Ambivalence in War Exhibitions. Millennium 34 (3): $841-862$.

Luscombe, Alex, Kevin Walby, and Justin Piché. 2018. Making Punishment Memorialization Pay? Marketing, Networks, and Souvenirs at Small Penal History Museums in Canada. Journal of Hospitality \& Tourism Research 42 (3): 343-364.

Macdonald, Sharon. 1998. Exhibitions of Power and Powers of Exhibition: An Introduction to the Politics of Display. In The Politics of Display: Museums Science, Culture, edited by Sharon Macdonald, 1-21. London: Routledge. 2008. Difficult Heritage: Negotiating the Nazi Past in Nuremberg and Beyond. New York: Routledge.

Masco, Joseph. 2005. The Billboard Campaign: The Los Alamos Study Group and the Nuclear Public Sphere. Public Culture 17 (3): 487-498.

Mason, Rhiannon, and Joanne Sayner. 2019. Bringing Museal Silence into Focus: Eight Ways of Thinking about Silence in Museums. International Journal of Heritage Studies 25 (1): 5-20.

Matthews, Sara. 2013. "The Trophies of their Wars": Affect and Encounter at the Canadian War Museum. Museum Management and Curatorship 28 (3): 272-287.

McTavish, Lianne. 2013. Defining the Modern Museum: A Case Study of the Challenges of Exchange. Toronto, CA: University of Toronto Press.

Mead, Matt. 2012. Plane Spotting, Military Portraiture, and Multiculturalism in the Imperial War Museum. Photography and Culture 5 (3): 281-293.

Meyer, Morgan. 2012. Placing and Tracing Absence: A Material Culture of the Immaterial. Journal of Material Culture 17 (1): $103-110$.

Monaghan, Jeffery. 2013. Mounties in the Frontier: Circulations, Anxieties, and Myths of Settler Colonial Policing in Canada. Journal of Canadian Studies 47 (1): 122-148.

Ott, Brian L., Eric Aoki, E., and Greg Dickinson. 2011. Ways of (not) Seeing Guns: Presence and Absence at the Cody Firearms Museum. Communication and Critical/Cultural Studies 8 (3): 215-239.

Packer, Jeremy, and Joshua Reeves. 2020. Killer Apps: War, Media, Machine. Durham, NC: Duke University Press.

Paglen, Trevor. 2010. Goatsucker: Toward a Spatial Theory of State Secrecy. Environment and Planning D: Society and Space 28 (5): 759-771.

Pauls, Haley, and Kevin Walby. 2020. Military, Meaning, and Tactical Myopia: Representations of Weapons at the Royal Canadian Artillery Museum. International Journal of Heritage Studies 26 (11): 1109-1122.

Pearce, Susan M. 2017. Museums, Objects, and Collections: A Cultural Study. Washington, DC: Smithsonian Institution.

Perkins, Chirs, and Martin Dodge. 2009. Satellite Imagery and the Spectacle of Secret Spaces. Geoforum 40 (4): 546-560.

Potolsky, Matthew. 2019. The National Security Sublime: On the Aesthetics of Government Secrecy. London: Routledge.

Rifkin, Mark. 2013. Settler Common Sense. Settler Colonial Studies 3 (3-4): 322-340.

Ryan, Gery W, and H. Russell Bernard. 2003. Techniques to Identify Themes. Field Methods 15 (1): 85-109.

Scott, James. 2015. Objects and the Representation of War in Military Museums. Museum \& Society 13 (4): $489-502$.

Shah, Nisha. 2017a. Gunning for War: Infantry Rifles and the Calibration of Lethal Force. Critical Studies on Security 5 (1): $81-$ 104.

- 2017b. Death in the Details: Finding Dead Bodies at the Canadian War Museum. Organization 24 (4): $549-569$.

Smith, Laurajane. 2006. Uses of Heritage. London: Routledge.

Sutherland, Claire. 2014. Borders of Belonging: The UK Border Agency Museum as a Nation-Building Site. In Challenging History in the Museum: International Perspectives, edited by Jenny Kidd, Sam Cairns, Alex Drago, and Amy Ryall, 175-186. London: Routledge. 
Taber, Nancy. 2020. "Lt. Col Smith with Unknown Bomb Girl”: Problematizing Narratives of Male Battlefield Heroism in Canadian Military Museums. Critical Military Studies: 1-19.

Tawil-Souri, Helga. 2016. Surveillance Sublime: The Security State in Jerusalem. Jerusalem Quarterly 68: 56-65.

Vance, Johnathan F. 1995. Tangible Demonstrations of a Great Victory: War Trophies in Canada. Material Culture Review 42 (1): 47-56.

Veeren, Elspeth van. 2018. The War on Terror is Hard to See: The Imperial War Museum's "Age of Terror" Exhibition and Absence as Curatorial Practice. Critical Military Studies 6 (3-4): 1-6.

Virilio, Paul. 1989. War and Cinema: The Logistics of Perception. London: Verso.

Walby, Kevin, Justin Piché, and Bethany Friesen. 2018. “...they didn’t just do it because it was a job”: Representing Wardens in Canadian Penal History Museums. International Journal of Law, Crime and Justice 53: 1-8.

Wall, Tyler, and Torin Monahan 2011. Surveillance and Violence from Afar: The Politics of Drones and Liminal Security-Scapes. Theoretical Criminology 15 (3): 239-254.

Wellington, Jennifer. 2017. Exhibiting War: The Great War, Museums, and Memory in Britain, Canada, and Australia. Cambridge, UK: Cambridge University Press.

Whitmarsh, Andrew. 2001. "We Will Remember Them": Memory and Commemoration in War Museums. Journal of Conservation and Museum Studies 7: 11-15.

Williams, Paul. 2008. Memorial Museums: The Global Rush to Commemorate Atrocities. London: Bloomsbury.

Wolfinger, Nick. 2002. On Writing Fieldnotes. Qualitative Inquiry 2 (1): 85-95.

Winter, Jay. 2010. The Performance of the Past: Memory, History, Identity. In Performing the Past: Memory, History and Identity in Modern Europe, edited by Karin Tilmans, Frank van Vree, and Jay Winter, 11-35. Amsterdam, NL: Amsterdam University Press.

2012. Museums and the Representation of War. Museum \& Society 10 (3): 150-163.

Woodward, Rachael. 2005. From Military Geography to Militarism's Geographies: Disciplinary Engagements with the Geographies of Militarism and Military Activities. Progress in Human Geography 29: 718-740.

Yanow, Dvora. 1998. Space Stories: Studying Museum Buildings as Organizational Spaces while Reflecting on Interpretive Methods. Journal of Management Inquiry 7 (3): 215-239. 